Portland State University

PDXScholar

8-17-2020

\title{
A New Perspective on Blue-Collar Work: Examining the Relevance of Common Career Development Theories for Blue-Collar Workers in Manufacturing
}

Sarah J. Barber

Portland State University

Follow this and additional works at: https://pdxscholar.library.pdx.edu/honorstheses

Part of the Training and Development Commons

Let us know how access to this document benefits you.

\section{Recommended Citation}

Barber, Sarah J., "A New Perspective on Blue-Collar Work: Examining the Relevance of Common Career Development Theories for Blue-Collar Workers in Manufacturing" (2020). University Honors Theses. Paper 930.

https://doi.org/10.15760/honors.953

This Thesis is brought to you for free and open access. It has been accepted for inclusion in University Honors Theses by an authorized administrator of PDXScholar. Please contact us if we can make this document more accessible: pdxscholar@pdx.edu. 


\title{
A New Perspective on Blue-Collar Work: Examining the Relevance of Common Career Development Theories for Blue-Collar Workers in Manufacturing
}

\author{
by \\ Sarah Barber \\ An undergraduate honors thesis submitted in partial fulfillment of the requirements for the \\ degree of \\ Bachelor of Science \\ in \\ University Honors \\ and \\ Business Administration: Human Resource Management \& Management and Leadership
}

Thesis Adviser

David Cadiz, Ph.D.

Portland State University

2020 


\section{Research Question:}

How effective are the four career development theories in reflecting the reality of career development for blue collar workers in the US manufacturing industry? 


\section{Introduction:}

Blue-collar work is integral to the United States. "Between 2018 and 2028, there could be as many as 2.4 million unfilled manufacturing jobs. That labor shortage would have an estimated \$2.5 trillion negative economic impact in the U.S” (Wilkie, 2019). Now is a more important time than ever to investigate better career development practices for blue collar workers to help address this gap. Blue-collar workers are defined as a, "working-class person who performs manual labor" (Adams, 2006). However, the term blue-collar is an umbrella term for hundreds of industries that make up the backbone of U.S. production. This study sought to investigate whether blue-collar workers in the manufacturing industry are being given sufficient career development opportunities based on the application of four career development theories.

Through researching existing literature, it was found that blue-collar career development is hardly studied. The limited studies that were found were either dated or not conducted in the United States, which may limit their generalizability to the U.S. blue-collar career development experience. To truly get a sense of blue-collar worker's careers, five interviews were conducted with current or past blue-collar workers in the manufacturing industry. The interview questions were based on four different career development theories: Holland's theory of vocational types, social cognitive career theory (SCCT), Super's developmental self-concept theory, and crystallization of vocational self-concept. In turn, the interviews were transcribed and evaluated for themes relevant to the career development theories. In developing themes based on the interviews, the goal was to understand how to offer career development opportunities for bluecollar workers in the manufacturing industry. 


\section{Background:}

Investigating blue-collar career development experiences is important given the lack of literature focused on this topic. From my research, I have found that my direct discourse community is reasonably scarce, consisting of a few psychologists and HR managers. Primarily, the study of career development focuses on white-collar work, typically with college-educated participants. This may be blue-collar workers are not concerned about a 'career' and only wish to have a job that provides a means for themselves and their families. However, the validity of these assumptions have not been tested through research.

Based on previous research, blue-collar workers want to develop, but it may not be the same way researchers view traditional career development. One integral article discusses the definition of the career success of blue-collar workers in France. Hennequin (2007) found that it can be broken into three primary categories: material, psychological, and social. Typically, it is assumed in careers that upward mobility is the goal. This study found that due to lack of upward mobility in most blue-collar jobs, the blue-collar workers interviewed chose to focus on psychological factors such as, "task enrichment, continuous training, and status recognition," rather than upward mobility (Hennequin, 2007 p.577). This demonstrates that career development is still vital to blue-collar workers. Hennequin argues the focus should be on training for new tasks and increasing the scope of their position rather than getting a new job within the organization.

Another article that exemplifies the differences in blue and white-collar career development, presents findings on the significance of occupational narratives for miners in Michigan (Lucas, 2004). Occupational descriptions have to do with blue-collar workers finding meaning and success by creating and telling stories that help form a community. They found that 
a miner community in Michigan adopted a Finnish term for "inner determination" called sisu to help create dignity and pride in their work. Through the concept of sisu, they were able to develop their success milestones despite not following the traditional trajectory of success for white-collar work. This was demonstrated when some miners told interviewers that they passed up supervisor roles. These workers who over time gained the respect of their peers by providing sound advice and demonstrating selfless leadership were offered positions as supervisors but turned down the promotions because they saw it as abandoning their friends and co-workers, moving from a more productive position to a less productive one.

One article that discusses blue and white-collar workers examine the difference in job conceptualization between the two groups ( $\mathrm{Hu}, 2010)$. Hu found that blue- and white-collar workers perceive individual job facets differently. Blue-collar workers believed that work was more routine and monotonous, whereas white-collar workers viewed their job as less systematic. However, when talking about co-workers, they found that blue-collar workers have a much more collaborative approach to work and a better sense of community than white-collar work. This could potentially explain one of the reasons why blue-collar workers do not have a desire to have upward mobility in their careers. Cooperative relationships with co-workers is more desirable than competitive relationships, and the community is more important than the position and title of the job.

From the previous studies on blue-collar workers, career development in the blue-collar field is prevalent. However, it does not present itself in the same way as white-collar career development. Therefore, to investigate how conceptually different blue-collar career development may be, this study examines development based on four career development theories that have been primarily used by white-collar workers. 


\section{Career Development Theories:}

Career development theories are the building blocks to understanding how employees would like to advance over the years and motivate them to produce quality work. These theories include Holland's theory of vocational types, social cognitive career theory, Super's developmental self-concept theory, and crystallization of vocational self-concept. Below, I will go into some detail of each career development theory, however, please refer to Appendix A (p.24) for a more in-depth summary.

Holland's vocational types theory breaks down people into six types: realistic, investigative, artistic, social, enterprising, and conventional. The realistic type is characterized by their mechanical and physical abilities. The artistic type is for people who are creative and do well in unconventional circumstances. The social type prefers working with people by either teaching, informing, or helping them. As for the enterprising type, they typically influence, or persuade people. Lastly, the conventional type refers to people who prefer structure and working with data. The premise of this theory is to align your work environment with your vocational type. This creates congruence in one's work as the environment values behavior they are likely to portray. This is an intriguing theory for blue-collar work because it provides the assumption that most blue-collar work falls under the category of "realistic." How could this potentially help blue collar workers? This could help to determine people who may have multiple types and may want to eventually transition in the company into supervisor roles rather than staying in the realistic model. And for the people who would like to stay in the realistic type for the length of their career, the career development interventions can be personalized to that career type.

Social cognitive career theory (SCCT) operates with the assumption that personal goals, self-efficacy, and outcome expectations all influence each other. To understand SCCT, it is crucial to understand the framework that it was built upon. The researchers behind SCCT, Robert 
Lent and colleagues (1996) took inspiration from Bandura's social cognitive theory and expanded it specifically for careers.

Essentially, Bandura argues that personal thoughts, feelings, and biology impact the environment and behavior (Bandura, 2000, Appendix B on p.25). An example of this is if a worker struggles with a new task, they may begin to show behavioral changes. They may get frustrated, they may not be able to focus, and most importantly, they may not try if they feel like they will not be successful. This also helps to define another term significant to both theories: self-efficacy.

Self-efficacy is the belief that a person feels they can successfully complete the task at hand. If they have high self-efficacy, they will be able to grow and learn easier than if their selfefficacy is low. Another aspect of Bandura's theory is behavior modeling. He discovered through his research that rather than trial and error, people generally attempt to watch others who know the task to learn how to do it themselves. This is called behavior modeling. With the background of Bandura, SCCT seeks to explain,

1. "How basic academic and career interests develop.

2. How educational and career choices are made.

3. How academic and career success is obtained" (Psychology iResearchNet, 2020). The three variables that are considered to influence each other are self-efficacy beliefs, outcome expectations, and personal goals.

Super's developmental self-concept theory has three aspects: self-concept, life span, and life space. The self- concept is a mixture of how we view ourselves and how others view us. Life span refers to breaking development into stages based loosely on age; they include growth, exploration, establishment, maintenance, and decline. Finally, life space refers to the breadth of 
someone's career. People have many different titles, even beyond their job positions, and that is what the life space is examining. For example, someone could be a mother, a basketball coach, and a lawyer. Therefore, it's essential to consider all roles a person has in their life because that will influence career development. This theory was innovative for its time. It recognizes the fact that people value different things at various stages of life and understands responsibilities that a person may have beyond their career.

A primary assumption of this theory that may be particularly relevant is that values and the desire for career development are going to vary throughout a person's career. For example, some blue-collar workers may decide to take a supervisor role to make more money, not because it is more fulfilling to them.

Finally, the crystallization of vocational self-concept states that vocational self-concept is based on four criteria: personality, interests, values, and abilities. Like Super's developmental self-concept theory, this theory states that as people grow older, they will begin to clarify and "crystallize" their place in the workforce. However, this theory differs from Super's due to the cyclical nature of crystallization of vocational self-concept. Tthe person may go through phases in which they have a clear professional concept; then, a life event triggers a change in personality, interest, values, and abilities that clouds the previously clear vocational perception. Going back to the example of a blue-collar worker taking on a supervisory role for more money, maybe an event such as having a child triggered a change in values since having a child typically encourages people to focus on finances. Overall, through this literature review, I discovered that blue-collar career development is mostly been ignored by the academic community despite encompassing a large part of the U.S. job market. 


\section{Methods:}

\section{Participants:}

The participants of this study were interviewed either in-person or over the phone due to the constraints of COVID-19. All five participants worked/ are currently working in manufacturing. Two of the participants are from Oregon, and the other three are from Colorado. The two Oregon participants worked at a paper mill for years together. The three Colorado participants worked at the same manufacturing company that produced machine parts for industrial engines. The machine company had a two-year academy that all three participants went through in which they got to attend classes for half the day to get an associate degree, and the other half of the day, they would train in all the different departments within the shop.

\section{Procedure:}

Each interview began with the signing of informed consent unless it was over the phone. In those cases, participants emailed their signed informed consent and were asked to verbally consent during the phone interview. The interviewer read from a standardized script introducing the research and explained what the interview consists of. Next, the participant took part in an activity where they were asked to map out their jobs on a career lifeline (Appendix C, p. 26). This was done to help participants begin thinking about their past jobs and hopefully allow them to highlight the significant points of their careers easier.

After the career lifeline activity, participants were asked questions on their first job, their most recent job, and their most significant job. For each role they were asked questions on: the duties and skills required for the position, what drew them to the position, how long they worked there, why they left, if they felt confident in the position, and if this position developed their career in any way (for a more detailed description of the questions that were asked, see Appendix D on p. 27). 


\section{Data Analysis:}

The interviews were recorded, transcribed, and evaluated for themes pertaining to the four career development theories. All documents containing identifying information of the participants were passcode protected on the researcher's laptop. Inductive reasoning was used to determine common themes between the personal narratives of various participants. The raw transcripts were printed and highlighted for key words. Those key words were then analyzed based on the career development theories and how applicable they are to these participant's personal narratives. Overall, the career development theories were analyzed within the personal narratives of the participants to determine which ones are most and least relevant to these bluecollar workers. 


\section{Results:}

In this section, each theory will be examined based on themes found in the interviews. For this study, pseudonyms will be used to reference each participant to protect their anonymity.

\section{Holland's Theory of Vocational Types:}

Holland's theory of vocational types groups of people into categories based on their skills and strengths. Based on the groupings, it appears that most blue-collar workers would be the "realistic" personality type. This personality is characterized by their interest in motor coordination and physically performing their work tasks. Through the interviews, it was found that all participants claimed in some form to have mechanical aptitude. For example, Ted stated that, "I liked cars and I was pretty mechanically inclined," when referencing why he decided to pursue his first job in manufacturing.

Another idea reflected across the interviews was that the positions they started their blue-collar career did not require a set of already acquired skills. For instance, John, who worked at a paper mill, stated that, "all you needed for that job was some common sense and some mechanical ability".

However, one aspect of the realistic type that was not consistent with what the participants had to say was the idea that the "realistic" personality type prefers to work alone or at least limit their time working with people. All of the participants later in their careers were either in a supervisory role where they had to train people or transition to a white-collar position. While it was a common theme for them to mention that they missed solely being able to work with their hands, it seemed as though they were happy in their higher-ranking position that involved managing people. This brings up the question of whether or not these participants have other potential personality types beyond just realistic. According to this theory, people can have multiple vocational types that they fit under, which is an area that could be investigated in future 
research. Overall, based on the participants, it seems that Holland's theory of vocational types applies to manufacturing positions since all described themselves as the "realistic" personality type.

\section{Social Cognitive Career Theory:}

The social cognitive career theory is based on the assumption that self-efficacy beliefs, outcome expectations, and goals are dependent upon each other. Based on these factors, it can impact how a career develops over time. One factor that may have had a negative impact on a few of the participants is not finishing their college degree. Four of the five participants mentioned that they either started college but never finished or they had the opportunity, and they sometimes regret that they did not take it. One participant suggested that, "I always felt ashamed I didn't go to college."

They go on to explain that it took them until their mid-30s before they finally accepted the identity of blue-collar worker. However, up until that point, they had always felt shame for not going to college and working in blue-collar positions. Jane, a person from the same company, stated that, "hindsight, I probably should've stayed with that and gotten a degree and kinda stuck with that. But, I didn't', in reference to one of her first positions at a semi-conductor company. This demonstrates that there is a certain percentage of blue-collar workers who had the personal goal of going to college and getting a degree, but due to extenuating circumstances, were not able to. This, in turn impacts their general self-efficacy because in today's society, people who do not go to college are often looked down upon. However, it did not seem to change their overall self-efficacy within their career. It appeared to be limited to their personal goal and how they were perceived socially.

For one participant, another factor that likely impacted her self-efficacy was being a woman in a male-dominated industry. Jane stated that, "we had a couple managers that really didn't think 
women should be in any kind of supervisory position and made it known on a constant basis." One manager, in particular would, "belittle anything my crew had done, and I was the only woman supervisor there." This was one of the reasons she ended up leaving that position. It is also highly likely that there were times in her job there that she felt her self-efficacy lower due to the negative environmental factor.

\section{Super's Developmental Self-Concept Theory:}

There are three main parts to Super's developmental self-concept theory, which include: selfconcept, life span, and life space. One fundamental assumption of the theory is that there are five stages in a person's career throughout their life: growth, exploration, establishment, maintenance, and decline. All five participants are currently either in the maintenance or decline stage. By completing the career lifeline activity and verbally talking through it with the participants, I was able to get a better understanding of their career as a whole. In particular, one participant is an example of someone who started work with a company right out of high school and stayed in that position for almost the whole duration of his career. Ted out of high school, went to a vocational education program through a manufacturing company. He would spend half of his day in the classroom learning about the different departments and basic skills. Then, the second half of the day would be spent on the manufacturing floor working. Ted ended up at this company for just shy of 40 years. The single company was able to take him through virtually all stages of his career, aside from growth. He said the academy was able to give him an overview of all the departments in the shop and gave him the necessary knowledge to be a machinist. Then, in his first position, he claimed that the knowledge he gained in the first five years, "prepared me for the rest of my career at the company." Clearly, the academy and onthe-job training that they offered at the company gave him the basic skills he needed to be 
successful at the start of his career. Then, his knowledge, skills, and abilities slowly expanded and grew as he moved upward through the company.

He continued to work his way up to higher positions until he was asked to help implement new software for the company. He took the opportunity and spent the last few years at the company implementing and training for the latest software. After that, he decided to retire early. He said that he felt, "we had implemented this new software, and it worked well. It was kind of like, I just won the super bowl, so I'm going to go out on top and retire". He ended up retiring and then decided to go back to work as a bus driver a few years later. This was interesting because it clearly shows the transition from maintenance to the decline stage. Ted had a very intense, important job that did not deal much with the mechanical aspect that he worked in for so long. Now, as a bus driver, he states that he likes it because it has the mechanical elements of keeping the bus operational, and he only works part-time. Ultimately, this was still a way of slowing down in his career that is accurately depicted by Super's theory.

Other participants, similar to Ted, claimed that they felt their current position they are in now is the accumulation of all their knowledge, skills, and abilities throughout their career. For example, John claimed that in reference to his position currently as a production planner, "you need a lot of technical knowledge," and you also need to, "know the capabilities and the capacities of the different equipment you're making your product on". Essentially, it is vital to know the background of the equipment to be successful in the white-collar position he is in now. Similarly, Charles claimed that his current position at the manufacturing company as a supplier quality engineer is the, "accumulation of past", going on to mention that he had gotten experience in quality, machining, and people skills in three different job positions that all aided in his performance. This determines that two people who are in the maintenance stage of their 
career have acquired the knowledge needed for the positions they wish to hold, and now the focus of their career is merely about making small adjustments to sustain themselves until they want to slow down and prepare for retirement.

\section{Crystallization of Vocational Self-Concept:}

The crystallization of vocational self-concept states that vocational self-concept is based on four criteria: personality, interests, values, and abilities.

Rather than stages like Super's theory, this theory asserts that career changes are cyclical. A life event will trigger a change in personality, interests, values, or abilities that will result in a change in vocational self-concept.

An example of when a person's vocational self-concept is crystalized is Charles, who claimed that his most important job was owning his own safe business because, "there is a portion within you that knows when everything is right. It's like when you put on a pair of shoes and they fit like they were made for you". He went on to explain that everything about the job worked for him, however, a life event of hurting his back forced him to sell the company and go back to the manufacturing company that he worked at before. In that time, he most likely had to re-adjust his vocational self-concept since he no longer owned his own company and he was back working for the manufacturing company.

John also had a somewhat similar experience where he continually adjusted his job position based on the needs of the company. He had been there so long and knew the business well enough that he was able to keep filling in for higher and higher positions. He said that there became a need for a safety and training manager because they were having safety issues, so he stepped into that position. After a few years of doing that, then he ended up taking the production planning role because they needed that position filled and no one else had the knowledge to do it. Each time, he had to adjust what he was doing, however, it always seemed to fit well with him. 
A differing but just as important experience is of Sam, who went through the academy and worked at the manufacturing company. He ended up learning two years of machining but the first day he was graduated and officially on the manufacturing floor, a supervisor immediately assigned him to an office job. This demonstrates how a life event can drastically change the path of the perceived vocational self-concept. However, it ended up being for the best because Sam went on to learn software development from the upward mobility he had in the office. This resulted in him transitioning to where he is now as the project manager of a software development team. The transition from his brief blue-collar experience prior to graduating the academy into a white-collar job presumably created uncertainty for a time. However, it is likely that he took it with stride and crystallized his vocational self-concept when he discovered his interest and skill in software development. 


\section{Discussion:}

\section{Holland's Theory of Vocational Types:}

Overall, Holland's theory of vocational types were fairly accurate for this group of participants. They all described their most important skill as having mechanical aptitude. This validates that these blue-collar workers fit with what was predicted by the theory; a realistic vocational type.

An aspect of Holland's theory that was not as accurate, was that a common characteristic of realistic vocational type is not wanting to work with people. It was found that all of the participants had some kind of role that required a lot of human interaction; especially as their career went on and they moved up within their respective companies. This suggests that their

preference of working with people is likely based on context. Since they were still working in an environment where manufacturing was happening and they still got to utilize their mechanical abilities, they did not mind working with people. But if they were put into a position where none of their mechanical skills were utilized, they may feel as though they do not fit well in that position.

While this theory can accurately depict a type of interest some blue-collar workers have, its's use for career development is limited. This theory is best suited for young people preparing to enter the workforce or considering higher education. Holland's theory based on this study seems to accurately predict vocational types for blue-collar workers just as well as white-collar workers. However, this is once again considering that it will only be able to help a person narrow down what industry or type of job they want to get into. Unfortunately, it does not offer much insight for blue-collar workers beyond that. Therefore, while this theory is applicable to blue-collar workers, it will not necessarily provide much aid in their career development beyond 
the beginning of their career. More research on this topic for blue collar workers, specifically looking into detail about having multiple "types" within the RIASEC model, may better inform the participant on the characteristics of a job they would excel at.

\section{Social Cognitive Career Theory:}

The most notable theme determined from SCCT, is that four of the five participants brought up the fact that they did not finishing college. This acknowledges the scrutiny that blue collar workers face for not attending college. This is especially true when it has become a cultural expectation in the U.S. for everyone to attend college, even if it not necessarily needed (Wilkie, 2019). It seems as though the participants believe that they are missing something in their career without it. While one participant specifically mentioned that she should have gotten a degree for an earlier position, all the other participants mentioned college but did not describe in detail why they would have finished college and what for. Ultimately, not all job positions need a college degree, therefore, it is important to offer alternative forms of training and developing skills for blue-collar workers who might be suited better in a more vocational education. All five participants were extremely successful in their own right and they did that through other forms of education. Therefore, it seems that they were able to fulfill a majority of their personal goals despite not going to college.

This is an important aspect to consider when creating a career development plan for bluecollar workers. Rather than only recommending jobs that require a college degree, it is important to provide legitimate career options for those people who might not need college to achieve all their personal career goals. Providing proper career planning for people in bluecollar work could help to remove the stigma of the work and legitimize it as a genuine career path. 
However, this is an issue beyond making career development plans. It should be the responsibility of the employer to provide quality development opportunities for blue-collar workers. The manufacturing company that three of the participants worked at had a valuable example of a built-in recruiting system that fed in committed employees and prepared them to work for the company. They did this through recruiting at high schools and providing a two-year academy that would be paid for by the company. This is an exemplary way of creating careerlong employees like Ted who are able to build upon their knowledge and expand into different positions. Overall, through proper career development interventions, blue-collar workers would be granted more opportunities and less uncertainty in their careers. In turn, reduced uncertainty for the employee means reduced uncertainty for the employer as well.

\section{Super's Developmental Self-Concept Theory:}

Through Super's developmental self-concept theory, it was discovered that three of the five participants felt that their last/ current position they are in is an accumulation of all the knowledge that they gained throughout the years. Ted phrased it clearly when he stated that it felt like his, "Superbowl". Similarly, John stated that it felt like an, "accumulation of past", in his current position as supplier quality engineer. Based on the information given by the participants, there are a decent amount of supervisory jobs in manufacturing that need the blue-

collar knowledge and experience that working in the company from an entry-level position easily provides.

Prior to the interviews, it was assumed that blue collar workers may not have the desire or the opportunities to advance through upward mobility. However, through understanding the occupational narratives of these participants, it is clear that there are blue collar workers who are highly skilled and who are great candidates to slowly move into supervisory roles throughout their career. Overall, it is once again about the companies putting resources into career 
development for their employees in order to see a return on investment. If a company is willing to hire high school kids, the company is at a significant advantage because they can determine what training they receive from the start.

\section{Crystallization of Vocational Self-Concept:}

The goal in providing work for an employee should be to help them with their crystallization of vocational self-concept. This can be a difficult task because even the employee themselves may not know what they want for their career yet. The most efficient way to address this is by providing resources within the company to help them develop into the positions that need to be filled with someone who has both the mechanical aptitude but also has the willingness to supervise people or manage bigger projects.

The other important aspect to consider is checking in on the skills of an employee and ensuring they would not be better suited in another position. This idea is highlighted through Sam's story. He spent two years learning about being a machinist but once he graduated and became a machinist, a supervisor either saw his potential for the office and asked him to move because of that. Or, it could be that they simply needed a spot filled. Regardless, Sam seemed to crystalize his self-concept through learning software development in the office despite being initially trained and hired to work as a machinist. Once again, in positions like these, background knowledge is important. Sam was likely still able to utilize his mechanical abilities for his job in the office, however, it likely was not to the same extent that he would have been expected to utilize them as a machinist. This therefore demonstrates the cyclical nature of crystallization of vocational self-concept through a blue-collar perspective.

\section{Limitations \& Future Research:}

There are several limitations of this research that are important to address in order to better understand the context of the results as well as to improve future research done on this 
topic. One limitation is that the results from the interviews may be biased due to the fact that the researcher personally knew three participants prior to the study. Small sample size is another limitation that makes this study hard to generalize. The next aspect to consider was the lack of consistent interview forms. Due to the COVID-19 pandemic, the researcher was only able to interview one participant in-person before the rest of the interviews were required to be done on the phone and not in-person. An aspect of the study design that could have been improved was asking questions about the participants first "adult job". This helped to gather detailed accounts of the companies that were the focus of the study, but it would have been beneficial to get more information about the start of their career since these were defining moments that likely impacted their professional lives.

In terms of future research, it would be beneficial to interview a bigger sample size and go into many different industries beyond manufacturing to see if the theories apply to other industries as well. It would also be productive to complete a study about people transitioning from blue to white-collar jobs; especially examining the white-collar positions that need basic blue-collar knowledge to qualify for the position. Overall, it seems as though the career development theories can be used for blue-collar workers effectively, however, there are already limitations to what theories can provide. What blue-collar work seems to be lacking based on this study is opportunities for people that want to excel and develop their career beyond where they are currently. This is exemplified in the fact that the academy that the three participants attended within the manufacturing company has since been closed. Research on other more formal educational opportunities in individual businesses could also be done to truly understand if they are worth the investment for certain industries. 


\section{Conclusion:}

In this study, four significant career theories were examined through the perspective of five past or current blue-collar workers. This was done in order to address the lack of research in the field of development on blue collar workers. Results found that the four career theories effectively apply to the participants in their careers which have significant implications for both potential employees as well as employers.

An important distinction to make is ultimately, why is this study still relevant? This study is relevant because once again, there is a significant blue-collar labor shortage in the U.S., and this is especially true for skilled work in the field. A professor of management at University of Pennsylvania states, "we cut back on vocational education programs starting a generation ago, in the belief that those programs tracked students into dead-end jobs" (Wilkie, 2019). However, what we are seeing instead is that the U.S. is in desperate need for semi-skilled blue-collar workers; meanwhile there are not enough professional jobs to employ all of the college graduates. It is the best use of time and resources to recruit and train blue-collar workers with mechanical interests, who can be put into entry level positions until they have time to learn and grow into more technologically or administratively advanced positions. Essentially, this could result in many more employees like Ted, who are able to go their whole career working for the company, expanding their knowledge, and providing significant contributions because of the detailed knowledge they have of the business. While this costs the business money up front, it should save money in the end if done properly. Blue collar career development is not an oxymoron, nor is it a mythical unicorn. If the people of this country are interested in filling the gap of skilled blue-collar jobs such as manufacturing, companies will need to consider advancing our collective knowledge of blue-collar career development as well as investing time and effort into better career development interventions. 


\section{References:}

Adams, R., \& Canak, W. (2006). Encyclopedia of Career Development- Blue Collar Workers. SAGE Reference . doi: http://dx.doi.org/10.4135/9781412952675.n19

Bandura, A. (2000). Exercise of human agency through collective efficacy. Current Directions in Psychological Science, 9, 75-78.

Bandura, A. (1984). Representing personal determinants in causal structures. Psychological Review, 91(4), 508-511. https://doi.org/10.1037/0033-295X.91.4.508

Barrett, T. C., \& Tinsley, H. E. (1977). Measuring vocational self-concept crystallization. Journal of Vocational Behavior, 11(3), 305-313. doi: 10.1016/00018791(77)90026-4

Chhajer, R., Rose, E. L., \& Joseph, T. (2018). Role of Self-efficacy, Optimism and Job Engagement in Positive Change: Evidence from the Middle East. Vikalpa: The Journal for Decision Makers, 43(4), 222-235. https://doi.org/10.1177/0256090918819396

Furnham, A. (2001). Vocational Preference and P-O Fit: Reflections on Holland's Theory of Vocational Choice. Applied Psychology: An International Review, 50(1), 5. https://doi.org/10.1111/1464-0597.00046

Hennequin, E. (2007, October 2). What "career success" means to blue-collar workers. Retrieved November 15, 2019, from https://www.emerald.com/insight/content/doi/10.1108/13620430710822029/full/html.

Hu, X., Kaplan, S., \& Dalal, R. (2010). An examination of blue- versus white-collar workers' conceptualizations of job satisfaction facets. Journal of Vocational Behavior., 76(2), 317.

Lent, R. W., \& Brown, S. D. (1996). Social cognitive approach to career development: An overview. Career Development Quarterly, 44(4), 310. https://doiorg.proxy.lib.pdx.edu/10.1002/j.2161-0045.1996.tb00448.x

Lucas, K \& Buzzanell, P.M. (2004) Blue-collar work, career, and success: occupational narratives of Sisu , Journal of Applied Communication Research, 32:4, 273-292, DOI: 10.1080/0090988042000240167

Luzzo, D. A. (1996). A Psychometric Evaluation of the Career Decision-Making Self Efficacy Scale. Journal of Counseling \& Development, 74(3), 276. https://doi.org/10.1002/j.15566676.1996.tb01865.x 
Muhar, J. (2016). Navigating through a sea of blue-collar presuppositions. Monthly Labor Review, 1-2. Retrieved from http://search.ebscohost.com/login.aspx?direct=true \&db=buh\&AN=115168681\&site=bsilive

Savickas, M. L. (1997). Career Adaptability: An Integrative Construct for Lifespan, Life-Space Theory. The Career Development Quarterly, 45, 247-259.

Social Sciences Questions and Answers. (n.d.). Retrieved July 7, 2020, from https://www.enotes.com/homework-help/what-is-triadic-reciprocal-causation-1759123 


\section{Appendices:}

\section{Appendix A:}

Career Development Theories Overview

\begin{tabular}{|c|c|c|}
\hline Theory & Description & Assumptions \\
\hline $\begin{array}{l}\text { Holland's Theory } \\
\text { of Vocational } \\
\text { Types }\end{array}$ & $\begin{array}{l}6 \text { vocational types: } \\
\text { - Realistic } \\
\text { - Investigative } \\
\text { - Artistic } \\
\text { - Social } \\
\text { - Enterprising } \\
\text { - Conventional }\end{array}$ & $\begin{array}{l}\text { Assumes only one } \\
\text { type of blue-collar } \\
\text { worker - realistic }\end{array}$ \\
\hline $\begin{array}{l}\text { Social Cognitive } \\
\text { Career Theory }\end{array}$ & $\begin{array}{l}\text { Self-efficacy impacts choices regarding: } \\
\text { - Behavior } \\
\text { - Motivation } \\
\text { - Thought pattern and responses } \\
\text { - Destiny idea }\end{array}$ & $\begin{array}{l}\text { - Assumes self- } \\
\text { efficacy impacts } \\
\text { career } \\
\text { - Assumes that } \\
\text { people learn from a } \\
\text { behavior model }\end{array}$ \\
\hline $\begin{array}{l}\text { Super's } \\
\text { Developmental } \\
\text { Self-Concept } \\
\text { Theory }\end{array}$ & $\begin{array}{l}\text { Career broken into } 5 \text { stages: } \\
\text { - Growth } \\
\text { - Exploration } \\
\text { - Establishment } \\
\text { - Maintenance } \\
\text { - Decline }\end{array}$ & $\begin{array}{l}\text { Assumes a } \\
\text { somewhat linear } \\
\text { path of career } \\
\text { development }\end{array}$ \\
\hline $\begin{array}{l}\text { Crystallization of } \\
\text { Vocational Self- } \\
\text { Concept }\end{array}$ & $\begin{array}{l}\text { Vocational self-concept includes } 4 \text { aspects: } \\
\text { - Personality } \\
\text { - Interests } \\
\text { - Values } \\
\text { - Abilities }\end{array}$ & $\begin{array}{l}\text { - Assumes interests } \\
\text { are somewhat } \\
\text { stagnant }\end{array}$ \\
\hline
\end{tabular}




\section{Appendix B}

\section{Triadic Reciprocal Causation Model}

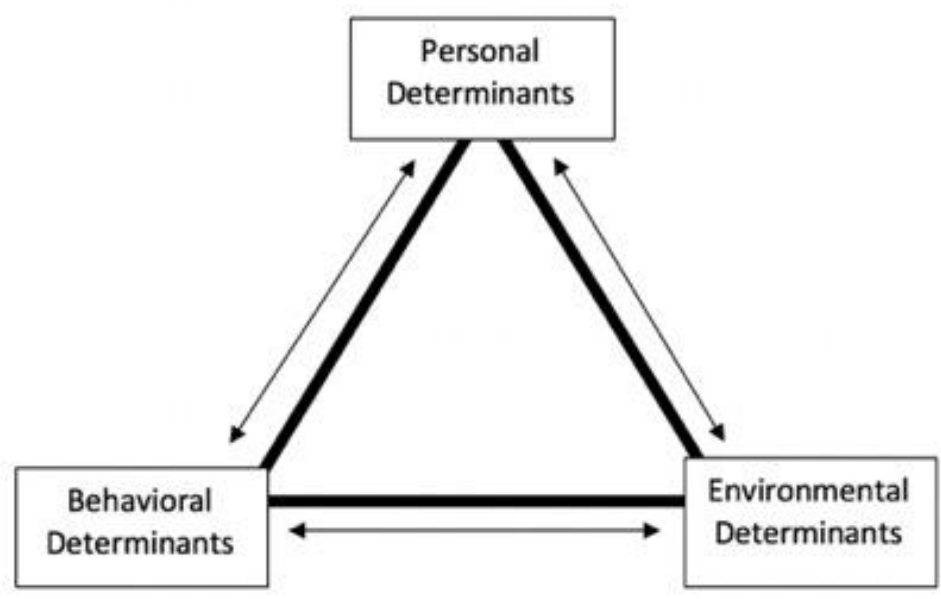

Retrieved from Enotes Social Sciences Questions and Answers. 2020. 


\section{$\underline{\text { Appendix C }}$}

\section{Career Lifeline Activity}

Career Lifeline Activity:

Please take 10 minutes to plot out the most significant highs and lows of your career

Highs

Age

15

30

45

60

75

90

Lows 


\section{$\underline{\text { Appendix D }}$}

\section{Interview Questions:}

1. Could you briefly walk me through what you wrote/drew on your paper?

First job:

2. What was the job that marked the start of your career? Briefly describe your duties and the skills required.

3. What drew you to this position?

4. How long did you work there?

5. Why did you end up leaving?

6. How would you describe your level of confidence in the work you did?

7. What knowledge, skills, experiences did you take from this position that aided you in your career? How did these gains happen, more informally or formally?

\section{Most recent job:}

8. What was your most recent job position? Briefly describe your duties and the skills required.

9. What drew you to this position?

10. How long did you work there?

11. Why did you end up leaving?

12. How would you describe your level of confidence in the work you did?

13. What knowledge, skills, experiences did you take from this position that aided you in your career? How did these gains happen, more informally or formally?

\section{Most significant job:}

14. What was your most significant job? Briefly describe your duties and the skills required.

15. Why was this job the most significant to you?

16. What drew you to this position?

17. How long did you work there?

18. Why did you end up leaving?

19. How would you describe your level of confidence in the work you did?

20. What knowledge, skills, experiences did you take from this position that aided you in your career? How did these gains happen, more informally or formally?

\section{General Work Questions:}

21. What currently motivates you in your job? Has this changed throughout your career?

22. Have any of the positions you've held align with your personality, interests, values, or abilities? Could you elaborate how the position aligned with this trait(s)?

23. Is there anything else you would like to share about your career that I didn't ask about? 